\title{
PENGARUH MODEL PEMBELAJARAN PENEMUAN (DISCOVERY LEARNING) TERHADAP KEMAMPUAN KONEKSI MATEMATIKA SISWA (Studi Eksperimen Terhadap Siswa Kelas VII SMPN 2 Sindangagung Kabupaten Kuningan Pada Pokok Bahasan Segiempat)
}

\author{
Alif Ringga Persada \\ Dosen Jurusan Tadris Matematika IAIN Syekh Nurjati Cirebon \\ Jalan Bypass Sunyaragi Kesambi Kota Cirebon \\ Kotaksurat_ringga@yahoo.co.id
}

\begin{abstract}
ABSTRAK
Kemampuan koneksi matematika siswa merupakan salah satu dari standar proses dalam pembelajaran matematika. Untuk mengoptimalkan kemampuan koneksi matematika siswa perlu dicarikan solusi. Salah satu alternatif yang dapat ditempuh adalah dengan menerapkan model pembelajaran Penemuan (Discovery Learning). Tujuan dari penelitian ini adalah untuk mengetahui respon siswa terhadap penggunaan model pembelajaran Penemuan (Discovery Learning), mengetahui kemampuan koneksi matematika siswa dan untuk mengetahui pengaruh model pembelajaran penemuan. Penelitian ini menggunakan metode kuantitatif yang bersifat eksperimen. Populasi target dalam penelitian ini adalah seluruh siswa SMPN 2 Sindangagung, sedangkan populasinya adalah seluruh siswa kelas VII SMPN 2 Sindangagung. Adapun yang menjadi sampel adalah kelas VII E, yang berjumlah 31 siswa. Teknik pengumpulan data terdiri dari angket penilaian siswa dan tes. Hasil penelitian dari uji hipotesis menunjukkan bahwa nilai thitung pada variabel model pembelajaran Penemuan (Discovery Learning) adalah 6,760, nilai pada t tabel adalah 2,045. Maka dapat disimpulkan bahwa $\mathrm{t}$ hitung $>\mathrm{t}$ tabel artinya terdapat pengaruh penerapan model pembelajaran Penemuan (Discovery Learning) terhadap kemampuan koneksi matematika siswa. Nilai rata-rata kemampuan koneksi matematika siswa juga baik yaitu 80,81 .
\end{abstract}

\section{ABSTRACT}

Ability of connection of student mathematics represent one of the standard process in mathematics study. To be optimal of ability of koneksi of student mathematics require to be looked for by solution. One of alternative which can be gone through by is by applying model the Invention study (Discovery Learning). Intention of this research is to know the respon student to use model the Invention study (Discovery Learning), knowing ability of connection of student mathematics and to know the influence model the invention study. This research use the quantitative method having the character of experiment. Goals population in this research is entire student SMPN 2 Sindangagung, while its population is entire student of class of VII SMPN 2 Sindangagung. As for becoming sample is class of VII E, amounting to 31 student. Technique of data collecting consisted of by the enquette of assessment of student and tes. Result of research from hypothesis test indicate that the value t count/calculate at variable model the Invention study (Discovery Learning) is 6,760, value of at t tables is 2,045. Inferential hence that $t$ count $>t$ of is tables of its meaning there are applying influence model the Invention study (Discovery Learning) to ability of connection of student mathematics. average value of Ability of good connection student mathematics also that is 80,81.

Ketword: Discovery Learning, Mathematics Connection

\section{PENDAHULUAN}

Begitu pentingnya matematika dalam kehidupan manusia, seharusnya bisa mendorong kita untuk merubah beberapa pandangan negatif siswa tentang matematika. Salah satu diantaranya bahwa matematika merupakan sosok yang sangat menakutkan dan sangat sulit untuk dipahami. Sadar atau tidak, bahwa sebenarnya segala pengetahuan akan terasa mudah untuk dipelajari ataupun dipahami jika kita mengetahui apa manfaatnya bagi kehidupan kita karena hal ini akan memperjelas tujuan dari pembelajaran yang sesungguhnya. Dan tujuan dari pembelajaran matematika itu sendiri adalah terbentuknya kemampuan bernalar pada diri siswa yang tercermin dalam kemampuan berpikir kritis, logis, sistematis, dan memiliki sifat objektif, jujur, disiplin dalam memecahkan suatu permasalahan baik dalam 
bidang matematika, bidang lain maupun dalam kehidupan sehari-hari.(PPPG,2004:1).

Sesuai dengan tujuan pembelajaran matematika seperti yang diungkapkan di atas, para ahli pendidikan dan para perancang kurikulum merumuskan empat kemampuan matematika yang diharapkan dapat dicapai siswa mulai dari tingkat dasar sampai tingkat menengah. Keempat kemampuan matematika tersebut adalah penalaran, pemecahan masalah, koneksi dan komunikasi. Keempat kemampuan matematika itu sesuai dengan pernyataan Adams dan Hamm tentang peran matematika yang digolongkan menjadi empat macam (Wijaya, 2012:6) yaitu:

1. Matematika sebagai suatu cara untuk berfikir

2. Matematika sebagai suatu alat

3. Matematika sebagai suatu pemahaman tentang pola dan hubungan

4. Matematika sebagai bahasa atau alat untuk berkomunikasi

Untuk bisa meningkatkan keempat kemampuan matematika itu biasa tercapai apabila dalam pembelajarannya siswa diarahkan oleh fasilitatornya. Seperti yang diungkapkan Nickson dalam Jajang(2005:5) berpendapat bahwa pembelajaran matematika adalah pemberian bantuan kepada siswa untuk membangun konsep-konsep dan prinsipprinsip matematika dengan kemampuan sendiri melalui proses internalisasi (arahan terbimbing) sehingga konsep atau prinsip itu terbangun. Pendapat tersebut menandakan bahwa guru dituntut untuk dapat mengaktifkan siswanya selama pembelajaran berlangsung. Proses pembelajaran tidak lagi berpusat pada guru melainkan pada siswa. Guru bukan mentransfer pengetahuan pada siswa tetapi membantu agar siswa membentuk sendiri pengetahuannya. Pendapat di atas tentang pembelajaran matematika, dapat disimpulkan bahwa pembelajaran matematika adalah merupakan serangkaian aktifitas guru dalam memberikan pengajaran terhadap siswa untuk membangun konsep-konsep dan prinsip-prinsip matematika dengan kemampuan sendiri melalui proses internalisasi, sehingga konsep atau prinsip itu terbangun dengan metode atau pendekatan mengajar dan aplikasinya agar dapat meningkatkan kompetensi dasar dan kemampuan siswanya. Oleh karena itu model pembelajaran sangat dibutuhkan dalam proses pembelajaran.

Model pembelajaran merupakan kerangka konseptual yang menggambarkan prosedur dalam mengorganisasikan pengalaman pembelajaran untuk mencapai tujuan pembelajaran. Model pembelajaran

berfungsi sebagai pedoman bagi guru dalam merencanakan dan melaksanakan kegiatan pembelajaran (Adi, 2000:45). Maka seorang guru perlu menguasai dan dapat menerapkan berbagai strategi pembelajaran yang meliputi pendekatan, metode, dan teknik pembelajaran secara spesifik.

Penguasaan model pembelajaran akan mempengaruhi keberhasilan peserta didik dalam pembelajaran. Proses pembelajaran pada satuan pendidikan diselenggarakan secara interaktif, inspiratif, menyenangkan, menantang, memotivasi peserta didik untuk berpartisipasi aktif serta memberikan ruang yang cukup bagi prakarsa, kreativitas dan kemandirian sesuai dengan bakat, minat dan perkembangan fisik serta psikologis peserta didik. Model pembelajaran yang dapat mendukung pembelajaran sesuai tujuan pembelajaran matematika yang diungkapkan di atas yaitu model pembelajaran penemuan (Discovery Learning). Menurut Wilcox (Nur, 2000). mengatakan bahwa dalam pembelajaran dengan penemuan siswa didorong untuk belajar sebagian besar melalui keterlibatan aktif mereka sendiri dengan konsep-konsep dan prinsip-prinsip, dan melakukan percobaan yang memungkinkan mereka menemukan prinsip-prinsipnya sendiri.

Model belajar ini akan memberikan siswa untuk bebas menyelidiki dan menarik kesimpulan dari hal-hal yang sedang dihadapinya. Guru sebagai fasilitator mengajak siswa untuk melakukan terkaan, intuisi, dan mencoba-coba (trial and error). Guru bertindak sebagai penunjuk jalan yang membantu siswa dalam menggunakan ide, konsep, dan keterampilan yang telah dimiliki oleah siswa untuk menemukan pengetahuan baru.

Tujuan pembelajaran yang ideal tersebut pada kenyataannya tidak selalu mudah dicapai oleh sekolah. Sebagai gambaran berdasarkan hasil wawancara peneliti dengan guru matematika kelas VII SMPN 2 Sindangagung, menyatakan bahwa memang proses belajar mengajar di 
kelas VII SMPN 2 Sindangagung sudah cukup optimal, tetapi siswa masih kesulitan dalam menyelesaikan soal terkait menuliskan masalah kehidupan sehari-hari ke dalam bentuk model matematika. Siswa juga masih kesulitan dalam menghubungkan antar obyek dan konsep dalam matematika. Selain itu, siswa juga masih kesulitan dalam menentukan rumus apa yang akan dipakai jika dihadapkan pada soal-soal yang berkaitan dengan masalah kehidupan sehari-hari.

Peneliti juga melakukan observasi dan wawancara kepada siswa terhadap masalah yang telah dikemukakan oleh guru bahwa siswa kesulitan dalam menghubungkan antar konsep yang sebelumnya telah diketahui oleh siswa dengan konsep baru yang akan siswa pelajari. Kesulitan-kesulitan siswa dalam belajar matematika yang telah disebutkan di atas merupakan unsur-unsur kemampuan koneksi matematika. Sehingga dari hasil wawancara dan hasil observasi menunjukkan adanya kemampuan koneksi matematika siswa kelas VII SMPN 2 Sindangagung yang masih belum optimal. Kemampuan koneksi matematika siswa yang belum optimal itu tidak sesuai dengan pendapat NCTM yang menyatakan bahwa standar proses dalam pembelajaran matematika yaitu kemampuan pemecahan masalah (problem solving), kemampuan penalaran (reasoning), kemampuan komunikasi (communication), kemampuan membuat koneksi (connection), dan kemampuan representasi (representation) (NCTM, 2000:29). Kemampuan siswa membuat koneksi merupakan salah satu dari standar proses dalam pembelajaran matematika. Dengan demikian kemampuan koneksi matematika merupakan salah satu kemampuan yang harus dimiliki dan tidak dapat dihindari kehadirannya saat mempelajari matematika. Hal ini karena karakteristik matematika itu terbentuk dari konsep-konsep yang saling terkait dan saling menunjang.

Untuk mengoptimalkan kemampuan koneksi matematika siswa khususnya pada siswa kelas VII SMPN 2 Sindangagung, perlu untuk dicarikan solusi. Salah satu alternatif yang dapat ditempuh untuk meningkatkan kemampuan koneksi matematika siswa adalah dengan cara menciptakan proses belajar yang menekankan pada kebermaknaan ilmu pengetahuan. Sebagaimana diungkapkan oleh Freudenthal bahwa proses belajar akan terjadi jika pengetahuan yang dipelajari bermakna bagi pembelajar. Maka salah satu pendekatan pembelajaran yang mengacu pada kebermakna ilmu pengetahuan adalah melalui pendekatan Kontruksivisme. Dimana dalam prinsip pembelajaran Konstruktivisme terdapat model pembelajaran Penemuan (Discovery Learning).

\section{KAJIAN TEORI}

Menurut Arends dalam buku Trianto (2010:51) Model pembelajaran adalah suatu perencanaan atau suatu pola yang digunakan sebagai pedoman dalam merencanakan pembelajaran di kelas atau pembelajaran tutorial. Model pembelajaran mengacu pada pendekatan pembelajaran yang akan digunakan, termasuk didalamnya tujuan pembelajaran, tahapan-tahapan pembelajaran, lingkungan pembelajaran, dan pengelolaan kelas. Menurut Adi (2000:45) model pembelajaran merupakan kerangka konseptual yang menggambarkan prosedur dalam mengorganisasikan pengalaman pembelajaran untuk mencapai tujuan pembelajaran. Model pembelajaran berfungsi sebagai pedoman bagi guru dalam merencanakan dan melaksanakan kegiatan pembelajaran. Menurut Suprihatiningrum (2013:143) mengatakan Model pembelajaran memiliki ciri khusus yang tidak dimiliki oleh strategi ataupun prosedur tertentu lainnya, yaitu:

1) Rasional teoritik yang disusun para pencipta atau pengembangannya.

2) Landasan pemikiran tentang apa dan bagai mana siswa belajar (tujuan pembelajaran yang akan dicapai).

3) Tingkah laku mengajar yang akan diperlukan agar model tersebut dapat dilaksanakan dengan berhasil.

4) Lingkungan belajar yang diperlukan agar tujuan pembelajaran dapat tercapai.

Pembelajaran dengan penemuan (Discovery Learning) menurut Nur dalam Suprihatiningrum (2013:241) merupakan suatu komponen penting dalam pendekatan kostrukstivis yang telah memiliki sejarah panjang dalam dunia pendidikan . Adapun teori menurut Wilcox (Nur, 2000:67) mengatakan bahwa dalam pembelajaran dengan penemuan siswa didorong untuk belajar sebagian besar melalui keterlibatan aktif mereka sendiri dengan konsep-konsep dan prinsip-prinsip, dan melakukan percobaan 
yang memungkinkan mereka menemukan prinsip-prinsipnya sendiri. Robet dalam Abu Ahmadi (1997:76) menyatakan bahwa "Discovery adalah proses mental dimana anak atau individu mengasimilasi konsep dan prinsip", jadi seorang siswa dikatakan melakukan discovery bila anak menggunakan proses mentalnya dalam usaha menemukan konsep-konsep atau prinsip-prinsip. Dalam menemukan konsep siswa melakukan pengamatan, menggolongkan, membuat dugaan, menjelaskan, menarik kesimpulan dan sebagainya. Cahyo (2013:100) juga berpendapat bahwa model pembelajaran penemuan (Discovery Learning) adalah metode mengajar yang mengatur pengajaran sedemikian rupa sehingga anak memperoleh pengetahuan yang sebelumnya belum diketahuinya tidak melalui pemberi tahuan, namun ditemukan sendiri. Nur dalam Suprihatiningrum (2013:248) guru yang menganut tujuan pokok Bruner yaitu menjadikan siswa mampu berdiri sendiri, harus mendorong siswa untuk mandiri sendiri mungkin sejak dari awal sekolah. Akan tetapi, bagaiman guru dapat membantu siswa tumbuh mandiri, salah satu jawaban yang palin sesuai dengan pembelajaran penemuan adalah memberikan kebebasan kepada siswa untuk mengikuti minat alamiah mereka. Berikut beberapa saran tambahan berdasarkan pada model pembelajaran penemuan dalam pembelajaran:

1. Mendorong siswa mengajukan dugaan awal dengan cara mengajukan pertanyaan membimbing.

2. Menggunakan bahan dan permainan yang bervariasi.

3. Memberikan kesempatan pada siswa untuk memuaskan keingintahuan mereka, meskipun mereka mengajukan gagasan yang tidak berhubungan langsung dengan pembelajaran.

4. Menggunakan sejumlah contoh kontras atau memperlihatkan perbedaan yang nyata dengan materi ajar topik-topik terkait.

Menurut Suryobroto (1986:45) dalam pembelajaran penemuan guru dan siswa mempunyai peranan-peranannya. Guru sebagai fasilitator berperan:

1. Menyiapkan tugas atau problem yang akan dipecahkan oleh siswa.

2. Memberikan klarifikasi-klarifikasi.

3. Menyiapkan seeting kelas.

4. Menyiapkan alat dan fasilitas belajar yang akan diperlukan.
5. Memberikan kesempatan pelaksanaan.

6. Sumber informasi, jika diperlukan oleh siswa.

7. Membantu agar siswa dapat merumuska sendiri kesimpulan dan implikasiimplikasinya.

Sedangkan bagi siswa yang belajar, mereka memiliki peranan;

1. Terjadinya proses mental yang tinggi dari siswa, sebab dengan aktivitas ini siswa:

- Mengasimilasi konsep.

- Mengasimilasi prinsip.

2. Pemecahan masalah (Problem Solving)

3. Selalu aktif

4. Tanggung jawab sendiri.

Berikut prosedur model penemuan (Discovery) menurut Abu Ahmadi dan Joko Tri Prasetya (1997:22):

1) Stimulation

Guru mengajukan persoalan atau menyuruh peserta didik membaca atau uraian yang memuat permasalahan.

2) Problem Statement

Anak didik diberi kesempatan mengidentifikasi berbagai permasalahan, sebagian besar memilihnya yang dipandang paling menarik dan fleksibel untuk dipecahkan. Permasalahan yang dipilih ini selanjutnya harus dirumuskan dalam bentuk pertanyaan atau hipotesis, yaitu jawaban sementara atas pertanyaan yang diajukan.

\section{3) Data Collection}

Untuk menjawab pertanyaan atau membuktikan benar tidaknya hipotesis ini,siswa diberi kesempatan untuk mengumpilkan data.

\section{4) Data Prosesing}

Semua informasi hasil bacaan, wawancara, observasi, diklasifikasi, ditabulasi, bahkan bila perlu dihitung dengan cara tertentu serta ditafsirkan pada tingkat kepercayaan tertentu. 5) Verification

Berdasarkan hasil pengolahan dan tafsiran atau informasi yang ada, pertanyaan atau hipotesis yang telah dirumuskan terdahulu itu kemudian dicek apakah terjawab atau tidak.

6) Generalitation

Tahap selanjutnya berdasarkan hasil verifikasi tadi, siswa belajar menarik kesimpulan atau generalisasi tertentu.

Koneksi matematika diilhami oleh karena ilmu matematika tidaklah terpartisi dari berbagai topik yang terpisah, namun matematika 
merupakan satu kesatuan. Selain itu, matematika juga tidak terpisah dari ilmu selain matematika dan masalah-masalah yang terjadi dalam kehidupan. Tanpa koneksi matematika, maka siswa harus belajar dan mengingat terlalu banyak konsep dan prosedur matematika yang saling terpisah (NCTM,2000:275)

Koneksi merupakan hubungan. Kaitannya dengan matematika lebih lanjut dikatakannya bahwa koneksi itu merupakan hubunganhubungan matematis dan saling pengaruh yang terjadi antar topik matematika, di luar matematika, dan di dalam minat-minat dan pengalaman siswa sendiri (Wahyudin,2008:45).

The National Council of Teachers of Mathematics (NCTM,2000:) membagi Koneksi matematika ke dalam tiga aspek kelompok koneksi, yaitu:

1) Aspek koneksi antar topik matematika. Aspek ini dapat membantu siswa menghubungakn konsep-konsep matematika untuk menyelesaikan suatu situasi permasalahan matematika

2) Aspek koneksi dengan disiplin ilmu lain. Aspek ini menunjukkan bahwa matematika sebagai suatu disiplin ilmu, selain dapat berguna untuk pengembangan disiplin ilmu yang lain, juga dapat berguna untuk menyelesaikan suatu permasalahan yang berkaitan dengan bidang studi lainnya.

3) Aspek koneksi dengan kehidupan seharihari. Aspek ini menunjukkan bahwa matematika dapat bermanfaat untuk menyelesaikan suatu permasalahan di kehidupan sehari-hari.

Kemampuan-kemampuan yang diharapkan setelah siswa mendapatkan pembelajaran yang menekankan pada aspek koneksi matematika menurut standar kurikulum NCTM adalah :

1) Siswa dapat menggunakan koneksi antar topik matematika.

2) Siswa dapat menggunakan koneksi antara matematika dengan disiplin ilmu lain.

3) Siswa dapat mengenali representasi ekuivalen dari konsep yang sama.

4) Siswa dapat menghubungkan prosedur antar representasi ekuivalen.

5) Siswa dapat menggunakan ide-ide matematika untuk memperluas pemahaman tentang ide-ide matematika lainnya.
6) Siswa dapat menerapkan pemikiran dan pemodelan matematika untuk menyelesaikan masalah yang muncul pada disiplin ilmu lain.

7) Siswa dapat mengeksplorasi dan menjelaskan hasilnya.

\section{METODOLOGI PENELITIAN}

Penelitian ini dilakukan di SMP Negeri 2 Sindangagung Kabupaten Kuningan, yang beralamat di Jl. Raya Kertayasa Desa Kertayasa Kecamatan Sindangagung Kabupaten Kuningan 45573.

Menurut Sugiyono (2012:2) metode penelitian pada dasarnya merupakan cara ilmiah untuk mendapatkan data dengan tujuan dan kegunaan tertentu. Metode penelitian yang penulis gunakan adalah metode penelitian kuantitatif yang berbentuk eksperimen. Data yang akan diolah dalam penelitian ini berhubungan dengan angka-angka yang dapat dihitung secara matematis dengan perhitungan statistika.

Desain eksperimen yang digunakan dalam penelitian ini adalah one short case study yaitu memberikan suatu treatment (perlakuan) dan selanjutnya diobservasi hasilnya. Desain ini dinyatakan dalam bentuk sebagai berikut: (Arikunto, 2006:85)

\section{X $O$}

$\mathrm{X}=$ treatment yang diberikan

$\mathrm{O}=$ Observasi

Populasi target dalam penelitian ini adalah seluruh siswa SMPN 2 Sindangagung sedangkan populasi terjangkau adalah siswa kelas VII SMPN 2 Sindangagung. Karena populasinya berada dalam kelompok-kelompok maka teknik sampilng yang digunakan dalam menentukan sampel penelitian adalah cluster random sampling. Menurut Sugiyono (2012:83) cluster random sampling adalah cara pengambilan sampel dari anggota populasi yang berada dalam kelompok atau cluster dengan menggunakan acak tanpa memperhatikan strata (tingkatan) dalam anggota populasi tersebut. Dengan demikian sampel yang digunakan dalam penelitian ini adalah sebanyak 1 kelas yakni kelas VII E yang berjumlah 31 siswa.

Sedangkan teknik pengumpulan data untuk variabel X (Model Discovery Learning) adalah menggunakan instrumen angket respon. Dan untuk variabel $\mathrm{Y}$ (Kemampuan koneksi matematika) adalah tes uraian. Teknik analisis data dalam penelitian ini menggunakan analisis regresi sederhana. 


\section{HASIL PENELITIAN}

Hasil penelitian yang diperoleh dari penelitian yang telah dilakukan. Hasil penelitian ini akan memaparkan tentang analisis data hasil skala non-tes mengenai respon siswa terhadap model pembelajaran penemuan (Discovery Learning) dan hasil tes kemampuan koneksi matematika siswa.

Tabel 1

Deskriptif Respon Siswa terhadap Model Discovery Learning)

\begin{tabular}{|l|l|}
\hline Mean & 82,94 \\
\hline Median & 85 \\
\hline Mode & 85 \\
\hline Varians & 37,662 \\
\hline Minimum & 71 \\
\hline Maksimum & 93 \\
\hline Std error of mean & 1,102 \\
\hline
\end{tabular}

Berasarkan table 1 bahwa rata-rata respon siswa terhadap model pembelajaran penemuan (Discovery Learning) sebesar 82,94 dengan nilai maximum sebesar 93, maka dapat disimpulkan bahwa respon siswa terhadap model pembelajaran penemuan (Discovery Learning) sangat baik. Adapun hasil rekaptulasi perolehan angket ditinjau berdasarkan dimensi dan indikator dapat dilihat melalui table berikut:

Tabel 2

Rekaptulasi dimensi dan Aspek Respon terhadap Model Discovery Learning)

\begin{tabular}{|c|c|c|c|c|c|}
\hline No & Dimensi & Indikator & Skor Maks & Jumlah Skor & $\%$ \\
\hline \multirow{3}{*}{1} & \multirow{3}{*}{ Menyelidiki } & $\begin{array}{l}\text { Mampu } \\
\text { menemukan } \\
\text { konsep yang } \\
\text { mendukung }\end{array}$ & 310 & 254 & 81,9 \\
\hline & & $\begin{array}{l}\text { Membuat } \\
\text { kesimpulan } \\
\text { sementara }\end{array}$ & 310 & 265 & 82,6 \\
\hline & & $\begin{array}{l}\text { Menguji } \\
\text { kesimpulan } \\
\text { sementara }\end{array}$ & 310 & 261 & 84,5 \\
\hline \multirow{3}{*}{2} & \multirow{3}{*}{$\begin{array}{l}\text { Mengasimilasi } \\
\text { konsep }\end{array}$} & $\begin{array}{l}\text { Menggunakan } \\
\text { konsep untuk } \\
\text { menyelesaikan } \\
\text { masalah }\end{array}$ & 310 & 259 & 83,5 \\
\hline & & $\begin{array}{l}\text { Mengecek hasil } \\
\text { temuan yang } \\
\text { sudah didapat }\end{array}$ & 310 & 243 & 78,4 \\
\hline & & $\begin{array}{l}\text { Mengaplikasikan } \\
\text { konsep dalam } \\
\text { menemukan } \\
\text { konsep baru }\end{array}$ & 155 & 126 & 81,3 \\
\hline \multirow{3}{*}{3} & \multirow{3}{*}{$\begin{array}{l}\text { Menemukan } \\
\text { sendiri atau } \\
\text { percobaan }\end{array}$} & $\begin{array}{l}\text { Hasil temuan } \\
\text { bersama teman }\end{array}$ & 310 & 266 & 84,2 \\
\hline & & $\begin{array}{l}\text { Hasil temuan } \\
\text { dengan bantuan } \\
\text { guru dan buku }\end{array}$ & 155 & 134 & 85,8 \\
\hline & & $\begin{array}{l}\text { Hasil temuan } \\
\text { sesuai konsep }\end{array}$ & 310 & 254 & 86,5 \\
\hline 4 & $\begin{array}{l}\text { Pengalaman } \\
\text { belajar }\end{array}$ & $\begin{array}{l}\text { Pengetahuan } \\
\text { baru }\end{array}$ & 310 & 254 & 83,9 \\
\hline
\end{tabular}




\begin{tabular}{|c|c|l|c|c|c|}
\hline No & Dimensi & Indikator & Skor Maks & Jumlah Skor & $\%$ \\
\hline & $\begin{array}{l}\text { Keterlibatan } \\
\text { siswa di kelas }\end{array}$ & 310 & 259 & 83,5 \\
\hline
\end{tabular}

Berdasarkan tabel 2 menggambarkan respon siswa terhadap Model Pembelajaran Penemuan (Discovery Learning) serta persentase masing-masing indikator pada angket. Terlihat bahwa indikator 5 memiliki nilai respon paling rendah dengan persentasi sebesar $78,4 \%$ dan yang memiliki respon siswa yang paling tinggi didapat di indikator 9 dengan persentase $86,5 \%$.

2. Kemampuan koneksi matematika

Tabel di bawah ini merupakan hasil gambaran perolehan hasil tes mengenai kemampuan koneksi matematika siswa pada sampel penelitian sebanyak 31 siswa.

Tabel 3

Deskripsi koneksi matematika siswa

\begin{tabular}{|l|l|}
\hline Mean & 80,81 \\
\hline Std error of mean & $\mathbf{2 , 0 4 1}$ \\
\hline Std deviation & 11,365 \\
\hline Varians & $\mathbf{1 2 9 , 1 6 1}$ \\
\hline Minimum & $\mathbf{5 5}$ \\
\hline Maksimum & $\mathbf{9 8}$ \\
\hline
\end{tabular}

Setelah tes uraian tentang kemampuan koneksi matematika disebarkan kepada siswa, maka didapat skor mean sebesar 80,81 artinya kemampuan koneksi matematika siswa secara keseluruhan memiliki rata-rata sebesar 80,81 dan koneksi tersebut tergolong tinggi. Standar deviasi didapat sebesar 11.365 yang artinya menunjukkan selisih simpangan antar skor dan data tersebut semakin dekat dengan sifat homogenitas. Nilai minimum yang didapat menunjukkan angka sebesar 55 yang artinya kemampuan koneksi matematika siswa yang terkecil secara keseluruhan adalah sebesar 55 dan nilai terbesar adalah 98. Adapun perolehan skor siswa berdasarkan tiap indikator dapat dilihat melalui tabel di bawah ini.

Tabel 4

Rekaptulasi indikator tes kemampuan koneksi matematika

\begin{tabular}{|c|c|c|c|c|c|}
\hline No & Dimensi & Indikator & Skor maks & Jumlah skor & $\%$ \\
\hline \multirow[b]{2}{*}{1} & \multirow[b]{2}{*}{$\begin{array}{c}\text { Koneksi antar } \\
\text { topik } \\
\text { matematika }\end{array}$} & $\begin{array}{l}\text { Dapat } \\
\text { menerapkan } \\
\text { konsep dalam } \\
\text { suatu topik } \\
\text { yang sama } \\
\text { (geometri) }\end{array}$ & 124 & 96 & 77,4 \\
\hline & & $\begin{array}{l}\text { Dapat } \\
\text { mengaitkan } \\
\text { prosedur } \\
\text { dalam topik } \\
\text { tertentu pada } \\
\text { topik lainnya } \\
\text { (bilangan } \\
\text { aljabar) }\end{array}$ & 248 & 204 & 82,3 \\
\hline 2 & $\begin{array}{c}\text { Koneksi antar } \\
\text { matematika } \\
\text { dengan ilmu } \\
\text { lain di luar } \\
\text { matematika }\end{array}$ & $\begin{array}{l}\text { Dapat } \\
\text { menerapkan } \\
\text { prosedur dari } \\
\text { materi } \\
\text { pembelajaran } \\
\text { pada disiplin } \\
\text { ilmu lain (seni } \\
\text { dan sejarah) } \\
\end{array}$ & 248 & 208 & 83,9 \\
\hline
\end{tabular}




\begin{tabular}{|c|c|l|c|c|c|}
\hline No & Dimensi & \multicolumn{1}{|c|}{ Indikator } & Skor maks & Jumlah skor & \% \\
\hline & & $\begin{array}{l}\text { Dapat } \\
\text { mengaitkan } \\
\text { hubungan } \\
\text { konsep antar } \\
\text { topik } \\
\text { matematika } \\
\text { dengan ilmu } \\
\text { lainnya (fisika } \\
\text { dan faroid) }\end{array}$ & 248 & 171 & 77 \\
\hline 3 & $\begin{array}{l}\text { Kapat } \\
\text { mengaitkan } \\
\text { matematika } \\
\text { dalam } \\
\text { kehidupan } \\
\text { sehari-hari } \\
\text { materi } \\
\text { peajaran } \\
\text { dalam } \\
\text { masalah } \\
\text { kehidupan } \\
\text { sehari-hari }\end{array}$ & 372 & 300 & 80,6 \\
\hline
\end{tabular}

Berdasarkan tabel 4 menggambarkan persentase nilai kemampuan koneksi matematika siswa dilihat perindikator. Terlihat bahwa indikator 1 terdiri dari satu soal yaitu soal nomor 1 persentasenya adalah sebesar $77,4 \%$, indikator 2 terdiri dari dua soal yaitu soal nomor 2 dan 3 dengan persentase sebesar $82,3 \%$,

indikator 3 terdiri dari dua soal yaitu soal nomor 4 dan 5 dengan persentase sebesar 83,9\%, indikator 4 dari dua soal yaitu soal nomor 6 dan 7 memiliki persentase sebesar $77 \%$ dan indikator 5 terdiri dari tiga soal yaitu 8,9 , dan 10 memiliki persentase sebesar $80,6 \%$. Terlihat indikator yang memiliki nilai persentase paling rendah yaitu indikator 4 dengan persentase sebesar $77 \%$ dan indikator yang memiliki nilai paling tinggi adalah indikator 3 dengan persentase sebesar 83,9\%.

Selanjutnya data yang didapat dari kedua instrumen adalah dilakukannya uji normalitas, homogenitas dan regresi sederhana. Berdasarkan perhitungan pada SPSS diperoleh tabel normalitas sebagai berikut.

Tabel 5

Uji normalitas

\begin{tabular}{|l|l|l|l|}
\hline \multirow{2}{*}{} & \multicolumn{3}{|c|}{ Kolmogorov Smirnov } \\
\cline { 2 - 4 } & Statistic & Df & Sig. \\
\hline $\begin{array}{l}\text { Unstandardized } \\
\text { residual }\end{array}$ & .110 & 31 & .200 \\
\hline
\end{tabular}

Berdasarkan tabel 5 diktahui nilai sig 0.200 yang artinya lebih dari 0,05. Hal ini menunjukan bahwa data berdistribusi normal. Selanjutnya uji homogenitas pada tabel berikut.

Tabel 6

Uji Homogenitas

\begin{tabular}{|l|l|l|l|}
\hline Levene Statistic & Df1 & Df2 & Sig. \\
\hline 2.379 & 7 & 14 & 0,079 \\
\hline
\end{tabular}

Berdasarkan tabel 6 diketahui nilai signifikansi sebesar 0,079 yang artinya lebih dari 0,05. Sehingga disimpulkan data berdistribusi homogen. 
Tabel 7

Coefficients regresi

\begin{tabular}{|c|c|c|c|c|c|}
\hline \multirow{2}{*}{ Model } & \multicolumn{2}{|c|}{ Unstandarized Coefficients } & $\begin{array}{c}\text { Standarized } \\
\text { Coefficents }\end{array}$ & \multirow[t]{2}{*}{$\mathrm{t}$} & \multirow[t]{2}{*}{ Sig. } \\
\hline & B & Std error & Beta & & \\
\hline (Constant) & $-39,325$ & 17,817 & & $-2,207$ & 0,035 \\
\hline $\begin{array}{l}\text { Model } \\
\text { Pembelajaran } \\
\text { Discovery } \\
\text { Learning }\end{array}$ & 1,448 & 0,214 & 0,782 & 6,760 & 0,000 \\
\hline
\end{tabular}

Berdasarkan tabel 7 menunjukkan regresi yang dicari nilai sig. dari konstanta $=0.010<0,05$ dan nilai sig. variabel $\mathrm{X}$ nya sebesar $0.000<0,05$ dari rumus persamaan awal $\mathrm{Y}=\mathrm{a}+\mathrm{bX}$. .

Dengan demikian persamaan untuk kedua variabel tersebut adalah:

$Y \quad=-39.325+1.448 X$

$\mathrm{Y}=$ kemampuan koneksi matematika siswa

$\mathrm{X}=$ model pembelajaran penemuan (Discovery Learning)

$\mathrm{a}=$ nilai konstanta harga $\mathrm{Y}$ ketika harga $\mathrm{X}=0$

$\mathrm{b}=$ Angka arah atau koefisien regresi linear

Karena nilai b atau koefisien regresi linear bernilai positif yaitu sebesar 1.448, artinya terjadi hubungan positif antara pembelajaran dengan menggunakan model pembelajaran penemuan (Discovery Learning) dengan kemampuan koneksi matematika siswa. Semakin tinggi pembelajaran dengan menggunakan model pembelajaran penemuan (Discovery Learning) maka semakin meningkat kemampuan koneksi matematikanya.

Tabel 8

Koefisien determinasi

\begin{tabular}{|l|l|l|l|l|}
\hline Model & R & R Square & Adjusted R Square & Std. Error f the estimate \\
\hline 1 & .782 & .612 & .598 & 7.202 \\
\hline
\end{tabular}

Berdasarkan perhitungan tersebut, diperoleh koefisien determinasi sebesar $61,2 \%$. Hal ini berarti pengaruh penggunaan model pembelajaran penemuan (Discovery Learning) (x) sebesar 61,2\% dan sisanya sebesar $38,8 \%$ ditentukan oleh faktor lain, seperti peran ganda guru, karakteristik karakteristik murid, budaya dan Lingkungan sekolah.

Berdasarkan tabel 7, hasil uji hipotesis diperoleh bahwa nilai t hitung sebesar 6,760 serta signifikansi sebesar 0,000. Untuk t tabel dengan $\mathrm{df}=29$ diperoleh sebesar 2,045. Karena t hitung lebih besar dari $\mathrm{t}$ tabel atau 6,760 $>2,045$ maka Ho di tolak artinya terdapat pengaruh antara pembelajaran model Discovery Learning terhadap kemampuan koneksi matematika siswa.

\section{PEMABAHSAN}

Kemampuan siswa membuat koneksi merupakan salah satu dari standar proses dalam pembelajaran matematika. Dengan demikian kemampuan koneksi matematika merupakan salah satu kemampuan yang harus dimiliki dan tidak dapat dihindari kehadirannya saat mempelajari matematika. Hal ini karena karakteristik matematika itu terbentuk dari konsep-konsep yang saling terkait dan saling menunjang.

Banyak siswa yang masih kesulitan untuk mengerjakan dan menyelesaikan soal-soal matematika yang berhubungan dengan koneksi matematika tersebut, hal ini karena kemampuan koneksi yang mereka miliki belum atau tidak terlatih dengan baik. Salah satu cara untuk melatih dan meningkatkan kemampuan koneksi matematika siswa adalah dengan memberikan permasalahanpermasalahan atau soal-soal matematika yang berkaitan dengan topik-topik yang berhubungan dengan matematika dan cara penyampaian materi atau model pembelajaran. Seperti yang telah diungkapkan oleh penulis bahwa cara mengajar seorang guru atau model pembelajaran sangat mempengaruhi peningkatan hasil belajar siswa. Salah satu model pembelajaran yang 
dapat meningkatkan koneksi matematika siswa yaitu model pembelajaran penemuan (Discovery Learning). Berdasarkan tahapantahapan menurut Robet dalam Abu Ahmadi (1997:76) dalam model pembelajaran penemuan (Discovery Learning) yang diantaranya adalah menyelidiki, mengasimilasi konsep, menemukan sendiri atau percobaan dan pengalaman belajar. Maka dimungkinkan munculnya pendapat, ide atau gagasan yang mereka buat dalam seluruh tahapan-tahapan

tersebut sehingga akan meningkatkan koneksi matematika siswa itu sendiri. Hasil perhitungan uji independent dan kelinieran regresi dengan menggunakan program SPSS 16.0 dapat penulis simpulkan bahwa t hitung yaitu $6,760>2,045$ maka terdapat hubungan yang independen. Selain itu hasil perhitungan uji linier sebesar 0,000 hal ini menunjukkan hubungan yang linier antara variabel dikarenakan taraf signifikannya kurang dari 0,05 . Sedangkan persamaan regresi kedua variabel yaitu sebesar $\mathrm{Y}=-39.325+1.448 X$. Karena nilai b atau koefisien regresi linear bernilai positif yaitu sebesar 1.448 , artinya terjadi hubungan positif antara pembelajaran matematika dengan menggunakan model pembelajaran penemuan (Discovery Learning) dengan kemampuan koneksi matematika siswa. Semakin tinggi model pembelajaran penemuan (Discovery Learning) maka semakin meningkat kemampuan koneksi matematika sesuai dengan penelitian yang dilakukan oleh Mega Kusuma Listyotami mahasiswi Fakultas Matematika dan Ilmu Pengetahuan Alam, Jurusan Pendidikan Matemarika Univarsitas Negeri Yogyakarta (UNY) Tahun 2011.

Hasil data analisis diketahui bahwa terdapat pengaruh yang signifikan antara model pembelajaran penemuan (Discovery Learning) terhadap kemampuan koneksi matematika siswa, ini dapat dilihat dari hasil perhitungan dengan menggunakan program SPSS 16.0 dari hasil analisis regresi memiliki nilai koefisien determinasi (R Square) sebesar 0,612 artinya $61,2 \%$ variabel dependen kemampuan koneksi matematika siswa $(\mathrm{Y})$ dijelaskan oleh variabel independen penerapan model pembelajaran penemuan (Discovery Learning) (X) dan sisanya $38,8 \%$ dijelaskan oleh variabel lain diluar variabel yang digunakan. Berdasarkan hasil analisis hipotesis terdapat data hasil penelirian, dilihat bahwa terdapat pengaruh yang signifikan anatara model pembelajaran
(Discovery Learning) terhadap kemampuan koneksi siswa. Hal ini dapat ditunjukan bahwa hasil t hitung $>t_{\text {tabel }}$ yaitu $6.760>2.045$ maka dapat disimpulkan bahwa model pembelajaran penemuan (Discovery Learning) berpangaruh terhadap kemampuan koneksi matematika siswa.

\section{KESIMPULAN}

1. Pembelajaran dengan menggunakan model pembelajaran penemuan (Discovery Learning) baik diterapkan di kelas VII E SMPN 2 Sindangagung Kabupaten Kuningan. Hal ini dapat dilihat dari hasil

2. rata-rata respon siswa pada hasil angket yang disebarkan peneliti persentase sebesar $84,10 \%$, artinya hasil respon siswa bernilai baik Kemampuan koneksi siswa yang diperoleh dari hasil tes kemampuan koneksi matematika siswa setelah diterapkan model pembelajaran penemuan (Discovery Learning) didapat nilai rata-rata sebesar 80,81. Ini menunjukkan nilai rata-rata siswa sangat baik.

3. Adanya pengaruh penerapan model pembelajaran penemuan (Discovery Learning) terhadap kemampuan koneksi matematika siswa. Dari hasil uji hipotesis menunjukkan bahwa thitung $>$ ttabel yaitu $6,760>2,045$ maka Ho ditolak, artinya ada pengaruh penerapan model pembelajaran penemuan (Discovery Learning) terhadap kemampuan koneksi matematika siswa. Dengan persamaan regresi untuk kedua variabel yaitu $\mathrm{Y}=$ $39.325+1.448 X$ dari persamaan tersebut koefisien regresi sebesar 1,448 menyatakan bahwa setiap penambahan (peningkatan) model pembelajaran penemuan (Discovery Learning) akan mempengaruhi kemampuan koneksi matematika siswa.

\section{SARAN}

1. Pembelajaran matematika dengan menggunakan model pembelajaran penemuan (Discovery Learning) dapat menjadi alternatif model pembelajaran bagi guru dalam rangka meningkatkan kemampuan

2. koneksi matematika siswa, khususnya bagi siswa yang mempunyai karakteristik yang sama dengan subyek penelitian. 
3. Kepada guru-guru matematika untuk mencoba mengimplementasikan model pembelajaran penemuan (Discovery Learning) secara bertahap, misalnya mulai dengan memberikan masalahmasalah realistik untuk mengetahui koneksi matematika siswa.

4. Karena kemampuan koneksi matematika merupakan hal yang sangat penting dalam pembelajaran matematika, maka kemampuan tersebut harus terus diteliti dan dikembangkan.

\section{DAFTAR PUSTAKA}

Ahmadi, Abu dan Joko Tri Prasetyo, 1997. Strategi Belajar dan Mengajar. Bandung: Pustaka Setia.

Arikunto, Suharsimi. 2006. Prosedur Penelitian: Suatu Pendekatan Praktik. Jakarta: Rineka Cipta.
Cahyo, Agus N, Panduan Aplikasi Teori-Teori Belajar Mengajar Teraktual dan terpopuler, 2013. Diva Prees.

Nur, Mohamad \& Wikandari, Prima Retno, Pengajaran Berpusat Kepadasiswa dan Pendekatan Kosntruktivistik dalam Pengajaran. Surabaya: PSMS UNESA. NCTM. Principles and Standards of School Mathematics. Reston. VA: NCTM PPPG, 2004. http://wawanjunaidi.blogspot.com/2010/06/pembelajaranmatematika.html diunduh padatanggal 09 Januari 2013 pada pukul 20:51 WIB.

Sugiyono. 2009. Metode Penelitian Kuantitatif, Kualitatif dan $R \& D$. Bandung: Alfabeta.

Sugiyono. 2009. Statistika untuk Penelitian. Bandung: Alfabeta.

Suprihatiningrum, Jamil. 2013. Strategi Pembelajaran: Teori dan Aplikasi. Yogyakarta: Ar-Ruzz Media.

The National Council of Teachers of Mathematics (NCTM). 2000. Principles and Standards for School Mathematics. Reston,VA: NCTM. 